DOI: $10.2478 / \mathrm{v} 10014-009-0015-\mathrm{z}$

Agrovoc descriptors: Humulus lupulus; hops; varieties; essential oils; podosphaera; genetic markers; disease resistance

Agris category code: H20 F30

\title{
Compounds of essential oils as markers of hop resistance (Humulus lupulus) to powdery mildew (Podosphaera macularis)
}

\author{
Andreja CERENAK ${ }^{1}$, Dragica KRALJ ${ }^{2}$, Branka JAVORNIK ${ }^{3}$
}

Received: March 14, 2009; accepted: July 21, 2009

Članek je prispel: 14. marca 2009; sprejet: 21. julija 2009

\begin{abstract}
Field assessments of resistance to powdery mildew of 103 hop cultivars, analyses of hop essential oil and correlation between the score for powdery mildew and the relative percentage of essential oil compounds were performed over three years. Seven susceptibility markers (peaks 29 (methyl-5-methyl-hexanoate), 30 (myrcene), 34 (iso-amyl-iso-butyrate), 38 (1-8-cineole), 56 (methyl-octanoate), 88 (methyl decanoate) and 122 (undetermined peak)) and seven resistance markers (peaks 112 (santalene), 114 (germacrene-D), 118 (alpha-selinene), 138 (cariophylene epoxide), 26, 135 and 158 (undetermined peaks)) were selected from peaks with a positive or negative correlation between powdery mildew scores and their presence in the essential oil of extremely susceptible or resistance cultivars. The number and value of resistance/susceptibility markers decreased with an increase in the level of cultivar susceptibility/resistance. Susceptible cultivars mainly appeared to contain North American germplasm, while more resistant cultivars belong to European hops. Analysis of the presence/absence of the selected markers showed that the absence of susceptibility markers, particularly 30 , 34 and 38 , can be of practical value in resistance hop breeding.
\end{abstract}

Keywords: Humulus lupulus L.; hop; Podosphaera macularis (Braun); powdery mildew; resistance; biochemical markers

\author{
KOMPONENTE ETERIČNEGA OLJA HMELJA (Humulus \\ lupulus) KOT MARKERJI ODPORNOSTI NA HMELJEVO \\ PEPELOVKO \\ (Podosphaera macularis)

\section{IZVLEČEK}

$\mathrm{V}$ raziskavi so bila izvedena opazovanja poljske odpornosti 103 sort hmelja na hmeljevo pepelovko $\mathrm{v}$ treh letih, analizirana so bila eterična olja hmelja vseh sort $\mathrm{z}$ določenimi relativnimi deleži posameznih komponent ter njihove korelacije $\mathrm{z}$ oceno poljske odpornosti na hmeljevo pepelovko. Sedem markerjev, povezanih z občutljivostjo (vrhovi 29 (metil-5-metil-heksanoat), 30 (mircen), 34 (izo-amil-izo-butirat), 38 (1-8-cineol), 56 (metil-oktanoat), 88 (metil dekanoat) in 122 (nedeterminiran vrh)) in sedem povezanih z odpornostjo na hmeljevo pepelovko (piki 112 (santalen), 114 (germakren-D), 118 (alfa-selinen), 138 (kariofilen epoksid), 26, 135 in 158 (nedeterminirani piki)) so bili izbrani na osnovi pozitivnih ali negativnih korelacij s poljskimi ocenami odpornosti na hmeljevo pepelovko in prisotnostjo vrhov $\mathrm{v}$ eteričnem olju ekstremno občutljivih in odpornih sort. Število in vrednost markerjev povezanih z odpornostjo/občutljivostjo se je zmanjšala s povečanjem stopnje občutljivosti/odpornosti sort. Občutljive sorte na hmeljevo pepelovko večinoma vključujejo severnoameriško dednino, medtem ko odpornejše sorte izvirajo iz evropske dednine. Analiza prisotnosti/odsotnosti izbranih markerjev kaže na praktično uporabnost odsotnosti markerjev povezanih z občutljivostjo, zlasti 30, 34 in $38 \mathrm{v}$ žlahtnjenju hmelja v smeri odpornosti na hmeljevo pepelovko.

Ključne besede: Humulus lupulus L.; hmelj; Podosphaera macularis (Braun); hmeljeva pepelovka; odpornost; biokemični markerji

\footnotetext{
1 Department for Plants, Soil and Environment, Slovenian Institute of Hop Research and Brewing, Žalec, Slovenia; Ph. D.; andreja.cerenak@ihps.si

2 Savinjska 89, Žalec, Slovenia; Ph. D.

3 Centre for Plant Biotechnology and Breeding, Biotechnical Faculty, University of Ljubljana, Ljubljana, Slovenia; Prof., Ph. D.
} 


\section{INTRODUCTION}

Hop (Humulus lupulus L.) is a perennial plant, the yield of which (hop cones) is used mainly in the brewing industry. It is grown in monoculture, so it is exposed to high pressure from different pests and diseases. Hop powdery mildew (Podosphaera macularis ssp. humuli (Braun), formerly called Sphaerotheca humuli (DC.) Burrill) is one of the oldest known hop diseases, and it can be extremely prolific. Heavy infestations can completely destroy a crop. In 1997, over 1200 ha of hop fields were destroyed in the USA due to the planting of highly susceptible cultivars, despite years of quarantine efforts (Turechek et al., 2001; Ocamb et al., 1999). In Germany, it was a disease of little significance until Northern Brewer, a susceptible cultivar, was planted extensively. Quarantine restrictions have prevented the disease from becoming established in South Africa or Australasia.

Powdery mildew infections on leaves and bines do not generally result in essential damage, but do serve as a source of flower and cone infestations, which can cause serious economic damage on susceptible cultivars. High alpha cultivars, in particular, have been prone to show increased susceptibility to powdery mildew (Seigner et al., 2005). Hop powdery mildew infection reduces the content of alpha bitter acids by $12-25 \%$ and thus also lowers the quality, not just the quantity of the yield (Krofta and Nesvadba, 2003).

One main aim of hop breeders is therefore to develop new cultivars with powdery mildew resistance, especially to reduce the amount of pesticides used to ensure top quality hop. The first hop cultivars possessing powdery mildew resistance were released in England (Darby, 1998b). Various American and German breeding programmes later also resulted in cultivars with good powdery mildew resistance. The Slovenian Institute of Hop Research and Brewing has bred 1 high alpha and 11 aroma cultivars that show moderate to good resistance levels for powdery mildew, 4 of which are planted on more than $95 \%$ of Slovene hop fields. Additional important aims in hop breeding include resistance to downy mildew and wilt, while high yield, quantity and quality of resins and essential oils remain the major objectives, since hop is an important ingredient in the beer-brewing process.

To date, eight powdery mildew resistance genes have been reported (Darby, 1998a; Seefelder et al., 2006). Resistance to powdery mildew conferred by these genes can be overcome by the development of new pathotypes. The sexual form of powdery mildew enables new combinations of genes; as a result new pathogen genotypes can develop, causing a decline in plant resistance (Royle, 1978; Darby, 1998a). Molecular markers associated with $R_{2}$ (deriving from Wye Target) and $R_{b u}$ (derived from Buket) genes for powdery mildew resistance have been developed (Seefelder et al., 2006). Such markers are applicable in marker assisted selection, which can shorten lengthily hop resistant breeding based on selection of resistance phenotypes.

It has been found that resistance to powdery mildew conferred by the $R_{B}$ gene (derived from Yeoman and Wye Challenger) is related to the production of selinenes in essential oils (Liyanage, 1973; Darby, $1998 \mathrm{~b}$ ) and this led us to study correlations between essential oil compounds and powdery mildew resistance in different hop cultivars. Our main goal was to identify the essential oil compounds associated with different responses of hop cultivars to powdery mildew infection and to develop appropriate markers. We obtained 7 susceptibility markers and 7 resistance markers showing good correlation with the susceptibility/resistance of hop cultivars, which could be used in breeding.

\section{MATERIAL AND METHODS}

\subsection{Material}

We used a collection of 103 hop cultivars for the study: landraces, wild and cultivated hops from different hopgrowing regions of the world (Australia, Belgium, Czech Republic, Denmark, England, France, Germany, Japan, New Zealand, Poland, Russia, Slovenia, South Africa, Serbia, USA and Ukraine). Two highly susceptible cultivars, Symphony and Yakima Cluster, perished in our hop collection because of disease and we therefore obtained essential oils from Tasmania and Oregon, respectively (Olson, 1998; Bobes et al., 1981).

\subsection{Assessments of powdery mildew resistance of hop} cultivars in the field

The analysed cultivars were cultivated in an experimental field under principles of good agriculture practise for a period of 3 years. Each cultivar was represented by 10 plants and the field was treated against pests (two spotted spider mites (Tetranychus urtacae), damson hop aphid (Phorodon humuli Schrank)) if the pest threshold was indicated. The field was not treated against fungal diseases, in order to gain reliable assessments of resistance to powdery mildew. The plants were visually inspected for symptoms of powdery mildew on leaves once per week. The most appropriate climatic conditions for disease development were in August. Resistance to powdery mildew was scored from 0 to 5 on collected technologically ripe cones (400/cultivar). Cultivars with no symptoms of 
disease were graded 0 , those with minimum symptoms $1(\leq 10$ $\%$ infected cones), more susceptible cultivars 2 (11-20\% infected cones), susceptible 3 (21-40\% infected cones), very susceptible 4 (41-60 \% infected cones) and extremely susceptible 5 (more than $60 \%$ of infected hop cones). The cultivars Symphony and Yakima Cluster were scored at 5 due to their known high susceptibility.

\subsection{Preparation and analysis of hop essential oil}

Analyses were performed on technologically ripe cones. The same number of cones from lower, middle and upper parts of all 10 plants was collected and average subsamples were used for analyses. After one month of storage at room temperature, the essential oil was distilled according to standard methods and specimens of the oil were analysed according to a standard GC procedure. Chromatographic analysis of essential oils recorded 187 peaks, shown as relative percentages (the sum of relative percentages of all 187 peaks of the chromatograph is 100). Eighty-eight peaks were determined by preparative chromatography combined with mass spectroscopy. In order to compare different quantities of individual peaks, relative percentages were converted into indexes. The index was defined as $\mathrm{X}=\left(\mathrm{O}_{\mathrm{n}} / \mathrm{O}_{\mathrm{Nmax}}\right) \times 100$, where $\mathrm{O}_{\mathrm{n}}$ is the relative percentage of the $\mathrm{N}$-th constituent of the essential oil and $\mathrm{O}_{\mathrm{Nmax}}$ is the maximum relative percentage for the same constituent in all analysed cultivars.

The data were analysed by factor analysis (Spearman, 1905) and the correlation between the score for powdery mildew and the relative percentage of essential oil compounds was calculated for each year. Potential markers were selected from among the indexes that were significant in positive or negative correlation with powdery mildew scores in all three years.

\section{RESULTS}

Forty-six out of 88 peaks showed significant correlations at $\mathrm{r}=0.15(\mathrm{p}=0.05), 29$ peaks were in negative and 17 in positive correlation with the scores of powdery mildew. Seven of the peaks with negative correlation were selected as resistance markers, since they were determined in the essential oil of resistant cultivars with a score of 0 (Cascade, Wye Target, Serebrjanka and Strisselspalt). Seven susceptibility markers were selected from peaks with positive correlation present in the essential oil of extremely susceptible cultivars which scored 5 (Symphony, Yakima Cluster and Galena). The resistance markers for powdery mildew selected in this way are: 112 (santalene), 114 (germacrene-D), 118 (alpha-selinene), 138 (cariophylene epoxide), 26, 135 and 158 (undetermined peaks), and the susceptibility markers are: 29 (methyl-5-methyl-hexanoate), 30 (myrcene), 34 (iso-amyl-iso-butyrate), 38 (1-8-cineole), 56 (methyloctanoate), 88 (methyl decanoate) and 122 (undetermined peak).

Table 1 shows the 103 cultivars included in the research with field susceptibility estimates obtained over 3 years. The cultivars are divided into 6 groups. Group 0 consists of 7 resistant cultivars (6.8\% of 103 analysed cultivars). Minimum symptoms of infection were observed on 12 cultivars placed in group 1 (11.6\%). The majority of genotypes $(60 ; 58.3 \%)$ belong to group 2 , more susceptible genotypes to group $3(10 ; 9.7 \%)$ and $4(12 ; 11.6 \%)$ while 3 genotypes $(2.9 \%)$ are in the group of most susceptible cultivars.

Selected peaks are presented in Table 1 as indexes estimated over three years. Indexes above a certain threshold $(25,40$ or 50$)$ were considered to be markers (bold) related to the susceptibility or resistance of hop to powdery mildew.
Markers 26, 112, 114, 118, 135, 138 and 158 were found in groups 0 and 1 of resistant cultivars. Two to five markers were present in the essential oil of all cultivars except Wye Northdown, which showed only one marker, indicating that the number of markers does not indicate the level of resistance. The cultivar Cascade, with inbred inheritance of Fuggle and Serebrjanka cultivars, is resistant in various hopgrowing regions.

The number and value of the resistance markers decreased as the level of susceptibility of cultivars increased, achieving very low indexes in group 5 . Marker 118 (alfa-selinen) had indexes above the threshold in the majority of resistant cultivars (groups 0 and 1) while it had a very low index in the groups scoring 4 and 5. Similarly, markers 138 and 158 indicate resistance to powdery mildew, since they presented with low indexes in susceptible groups 4 and 5.

Susceptibility markers 29, 30, 34, 38, 56, 88 and 122 had low indexes in resistant cultivars, while their indexes noticeably increased in susceptible cultivars, reaching index 100 in some cases in groups 4 and 5 . The absence of resistance markers and presence of markers 56 and 88 was very characteristic of the three maximum susceptible cultivars: Symphony, Yakima Cluster and Galena. The genotype Symphony had 5 susceptibility markers, of which 56 and 122 had extremely high indexes. Symphony is known to be a highly susceptible cultivar in the USA, where a serious economic disaster occurred in hop fields in 1997 (Ocamb et al., 1999). The essential oil of susceptible old American cultivar Yakima Cluster includes 5 susceptibility markers, of which marker 30 had the highest index. Galena, the third cultivar in group 5, had all seven susceptibility 
markers, with extremely high values of markers 34 and

88 .

Table 1: Evaluation of susceptibility of cultivars to powdery mildew with values of relevant markers; indexes are bolded and thresholds are italic.

\begin{tabular}{|c|c|c|c|c|c|c|c|c|c|c|c|c|c|c|c|}
\hline Cultivar & $\begin{array}{l}\text { Field } \\
\text { assesment }\end{array}$ & $\begin{array}{l}\mathbf{2 6} \\
25\end{array}$ & $\begin{array}{c}112 \\
25\end{array}$ & $\begin{array}{c}114 \\
25\end{array}$ & $\begin{array}{c}118 \\
25\end{array}$ & $\begin{array}{c}135 \\
40\end{array}$ & $\begin{array}{c}138 \\
40\end{array}$ & $\begin{array}{c}158 \\
40\end{array}$ & $\begin{array}{l}29 \\
40 \\
\end{array}$ & $\begin{array}{l}30 \\
50\end{array}$ & $\begin{array}{l}34 \\
40 \\
\end{array}$ & $\begin{array}{l}38 \\
50 \\
\end{array}$ & $\begin{array}{l}\mathbf{5 6} \\
40 \\
\end{array}$ & $\begin{array}{l}\mathbf{8 8} \\
40\end{array}$ & $\begin{array}{c}122 \\
40\end{array}$ \\
\hline Cascade & 0 & 9 & 82 & 23 & 20 & 100 & 38 & 27 & 17 & 26 & 32 & 9 & 8 & 5 & 0 \\
\hline Wye Target & 0 & 22 & 3 & 57 & 12 & 12 & 57 & 83 & 2 & 49 & 36 & 43 & 25 & 38 & 6 \\
\hline Serebrjanka & 0 & 4 & 27 & 64 & 33 & 15 & 100 & 78 & 5 & 36 & 33 & 9 & 12 & 3 & 6 \\
\hline Pride of Ringwood & 0 & 0 & 100 & 100 & 100 & 15 & 100 & 78 & 0 & 43 & 8 & 10 & 30 & 33 & 4 \\
\hline Nadwislansky & 0 & 0 & 0 & 45 & 23 & 35 & 87 & 72 & 26 & 40 & 0 & 20 & 14 & 14 & 16 \\
\hline Univerzal & 0 & 0 & 20 & 32 & 13 & 17 & 60 & 40 & 0 & 39 & 2 & 0 & 19 & 12 & 10 \\
\hline Strisselspalt & 0 & 27 & 36 & 53 & 41 & 30 & 13 & 14 & 12 & 45 & 4 & 20 & 17 & 4 & 4 \\
\hline Iwanovecky & 1 & 0 & 46 & 24 & 11 & 24 & 38 & 42 & 5 & 32 & 5 & 27 & 14 & 14 & 11 \\
\hline Zlatan & 1 & 0 & 0 & 29 & 11 & 13 & 42 & 33 & 0 & 20 & 0 & 30 & 14 & 8 & 16 \\
\hline Tutsham & 1 & 0 & 0 & 71 & 100 & 54 & 5 & 25 & 10 & 22 & 4 & 36 & 6 & 1 & 3 \\
\hline Kogneao & 1 & 13 & 64 & 60 & 39 & 33 & 0 & 27 & 19 & 30 & 2 & 27 & 10 & 1 & 3 \\
\hline Omega & 1 & 0 & 100 & 75 & 69 & 7 & 15 & 28 & 14 & 18 & 15 & 40 & 16 & 0 & 5 \\
\hline Pioneer & 1 & 36 & 41 & 44 & 33 & 2 & 3 & 29 & 0 & 49 & 28 & 27 & 8 & 18 & 4 \\
\hline First Gold & 1 & 82 & 44 & 50 & 48 & 6 & 2 & 20 & 0 & 62 & 35 & 27 & 11 & 6 & 4 \\
\hline Herald & 1 & 100 & 46 & 53 & 48 & 6 & 1 & 19 & 0 & 47 & 38 & 82 & 11 & 5 & 4 \\
\hline Wye Saxon & 1 & 77 & 36 & 35 & 33 & 10 & 8 & 23 & 0 & 56 & 20 & 90 & 11 & 4 & 3 \\
\hline Wye Challenger & 1 & 0 & 29 & 36 & 51 & 4 & 4 & 31 & 2 & 45 & 56 & 60 & 23 & 10 & 5 \\
\hline Wye Northdown & 1 & 4 & 0 & 25 & 8 & 4 & 7 & 16 & 0 & 57 & 48 & 40 & 22 & 4 & 4 \\
\hline Wye Viking & 1 & 27 & 12 & 25 & 18 & 10 & 4 & 29 & 17 & 70 & 40 & 70 & 22 & 4 & 5 \\
\hline Hallertauer MTF & 2 & 4 & 6 & 39 & 8 & 16 & 41 & 43 & 14 & 37 & 13 & 20 & 14 & 3 & 4 \\
\hline Urožajni & 2 & 0 & 0 & 26 & 20 & 21 & 29 & 44 & 2 & 36 & 1 & 36 & 0 & 0 & 0 \\
\hline White Bine & 2 & 0 & 49 & 67 & 47 & 21 & 52 & 35 & 5 & 26 & 20 & 10 & 9 & 0 & 2 \\
\hline Emerald & 2 & 9 & 13 & 51 & 39 & 33 & 6 & 25 & 33 & 39 & 33 & 27 & 8 & 3 & 11 \\
\hline Star & 2 & 0 & 14 & 29 & 7 & 72 & 100 & 12 & 10 & 30 & 14 & 45 & 9 & 1 & 5 \\
\hline Backa & 2 & 4 & 3 & 35 & 10 & 100 & 37 & 19 & 14 & 26 & 6 & 27 & 7 & 4 & 3 \\
\hline Chang bei 2 & 2 & 4 & 0 & 46 & 22 & 17 & 36 & 49 & 14 & 43 & 3 & 20 & 27 & 9 & 4 \\
\hline Early Bird Golding & 2 & 40 & 15 & 27 & 8 & 11 & 4 & 11 & 0 & 38 & 11 & 45 & 11 & 3 & 4 \\
\hline Eastwell Golding & 2 & 4 & 5 & 29 & 7 & 15 & 13 & 13 & 0 & 39 & 5 & 45 & 14 & 6 & 4 \\
\hline Mathon & 2 & 0 & 6 & 30 & 14 & 10 & 7 & 15 & 0 & 23 & 13 & 40 & 16 & 4 & 6 \\
\hline Fuggles & 2 & 4 & 0 & 25 & 6 & 9 & 10 & 12 & 7 & 33 & 20 & 40 & 9 & 2 & 4 \\
\hline Savinjski golding & 2 & 5 & 26 & 25 & 8 & 10 & 10 & 8 & 7 & 39 & 17 & 36 & 9 & 1 & 5 \\
\hline Saladin & 2 & 0 & 0 & 27 & 8 & 19 & 8 & 23 & 2 & 39 & 13 & 45 & 7 & 1 & 5 \\
\hline Orion & 2 & 13 & 10 & 38 & 8 & 10 & 14 & 28 & 14 & 43 & 25 & 30 & 9 & 3 & 10 \\
\hline Osvaldov klon 126 & 2 & 0 & 0 & 28 & 6 & 9 & 9 & 13 & 10 & 39 & 16 & 40 & 7 & 0 & 4 \\
\hline Osvaldov klon 72 & 2 & 0 & 0 & 25 & 11 & 23 & 16 & 36 & 0 & 38 & 0 & 0 & 20 & 13 & 13 \\
\hline Coobs & 2 & 9 & 3 & 32 & 9 & 11 & 8 & 15 & 2 & 35 & 6 & 30 & 13 & 4 & 4 \\
\hline Nordgard 978 & 2 & 0 & 5 & 36 & 10 & 17 & 37 & 36 & 21 & 30 & 26 & 27 & 36 & 6 & 10 \\
\hline Groene Bel & 2 & 0 & 5 & 32 & 12 & 9 & 23 & 18 & 7 & 31 & 15 & 27 & 4 & 0 & 1 \\
\hline Spalter & 2 & 0 & 0 & 18 & 14 & 20 & 19 & $\mathbf{5 0}$ & 5 & 36 & 3 & 27 & 17 & 10 & 10 \\
\hline Sirem & 2 & 0 & 0 & 16 & 12 & 27 & 13 & 50 & 7 & 42 & 2 & 27 & 12 & 14 & 9 \\
\hline Kostromsky & 2 & 0 & 0 & 15 & 8 & 26 & 26 & 53 & 7 & 42 & 1 & 27 & 17 & 9 & 16 \\
\hline Žitomirski klon34 & 2 & 0 & 0 & 12 & 11 & 28 & 16 & 50 & 7 & 37 & 1 & 36 & 13 & 11 & 11 \\
\hline Žitomirski klon 18 & 2 & 0 & 0 & 5 & 26 & 46 & 14 & 38 & 0 & 30 & 0 & 20 & 12 & 6 & 0 \\
\hline Tardif de Bourgogne & 2 & 0 & 0 & 21 & 12 & 22 & 43 & 33 & 26 & 33 & 0 & 10 & 27 & 16 & 16 \\
\hline Žateški pol.červenjak & 2 & 0 & 21 & 20 & 12 & 21 & 48 & 34 & 5 & 47 & 4 & 27 & 13 & 13 & 10 \\
\hline Hallertauer Gold & 2 & 32 & 8 & 18 & 8 & 18 & 17 & 33 & 36 & 40 & 18 & 45 & 30 & 8 & 6 \\
\hline Mt. Hood & 2 & 73 & 0 & 43 & 10 & 26 & 79 & 100 & 45 & 27 & 57 & 0 & 14 & 29 & 3 \\
\hline Ringwood special & 2 & 0 & 8 & 28 & 16 & 24 & 99 & 55 & 48 & 43 & 5 & 27 & 28 & 34 & 11 \\
\hline Yeoman & 2 & 45 & 26 & 39 & 52 & 12 & 5 & 17 & 21 & 49 & 51 & 82 & 11 & 1 & 4 \\
\hline Comet & 2 & 4 & 51 & 34 & 58 & 41 & 17 & 38 & 14 & 55 & 12 & 50 & 8 & 8 & 12 \\
\hline Kirin 1 & 2 & 4 & 36 & 64 & 39 & 43 & 21 & 23 & 0 & 47 & 41 & 27 & 10 & 3 & 2 \\
\hline Hueller Biterer & 2 & 9 & 41 & 70 & 31 & 35 & 5 & 20 & 29 & 66 & 33 & 30 & 14 & 4 & 13 \\
\hline Chang bei 1 & 2 & 0 & 38 & 43 & 34 & 10 & 13 & 26 & 2 & 35 & 45 & 27 & 21 & 6 & 8 \\
\hline
\end{tabular}




\begin{tabular}{|c|c|c|c|c|c|c|c|c|c|c|c|c|c|c|c|}
\hline Zenith & 2 & 0 & 43 & 55 & 72 & 7 & 4 & 17 & 7 & 33 & 17 & 50 & 17 & 4 & 5 \\
\hline Neuroter & 2 & 0 & 26 & 29 & 13 & 31 & 24 & 50 & 45 & 28 & 0 & 20 & 17 & 13 & 20 \\
\hline College Cluster & 2 & 0 & 40 & 31 & 12 & 7 & 14 & 20 & 36 & 42 & 57 & 90 & 16 & 8 & 4 \\
\hline Poljski klon 34 & 2 & 0 & 25 & 31 & 12 & 16 & 25 & 38 & $\mathbf{5 0}$ & 32 & 3 & 20 & 22 & 15 & 15 \\
\hline Celeia & 2 & 0 & 24 & 39 & 26 & 9 & 15 & 14 & 10 & 63 & 6 & 39 & 22 & 4 & 5 \\
\hline Cerera & 2 & 0 & 22 & 34 & 27 & 0 & 15 & 7 & 12 & 58 & 16 & 39 & 18 & 3 & 0 \\
\hline Aromat & 2 & 0 & 24 & 26 & 11 & 27 & 27 & 38 & 43 & 31 & 0 & 20 & 16 & 11 & 15 \\
\hline Wuertemberger & 2 & 4 & 13 & 36 & 12 & 16 & 13 & 38 & 12 & 30 & 4 & 20 & 9 & 3 & 1 \\
\hline Saazer & 2 & 0 & 29 & 13 & 27 & 28 & 52 & 22 & 2 & 20 & 45 & 26 & 38 & 0 & 4 \\
\hline Perle & 2 & 5 & 3 & 28 & 7 & 15 & 7 & 20 & 2 & 45 & 23 & 50 & 7 & 4 & 8 \\
\hline Nordgard 1478 & 2 & 0 & 15 & 26 & 8 & 13 & 25 & 21 & 10 & 37 & 22 & 55 & 14 & 3 & 5 \\
\hline Sara & 2 & 36 & 64 & 9 & 61 & 6 & 10 & 18 & 21 & 49 & 18 & 70 & 1 & 0 & 0 \\
\hline Poljski klon 12 & 2 & 0 & 0 & 26 & 7 & 8 & 6 & 12 & 2 & 32 & 29 & 50 & 7 & 0 & 4 \\
\hline Kruglak Siriak & 2 & 0 & 0 & 17 & 12 & 29 & 21 & 48 & 64 & 40 & 2 & 27 & 19 & 12 & 16 \\
\hline Brausteren & 2 & 31 & 8 & 31 & 6 & 11 & 3 & 28 & 2 & 60 & 29 & $\mathbf{5 0}$ & 8 & 3 & 5 \\
\hline Record & 2 & 9 & 8 & 26 & 7 & 16 & 10 & 28 & 2 & 51 & 26 & 70 & 13 & 3 & 3 \\
\hline Estera & 2 & 0 & 0 & 30 & 9 & 15 & 5 & 11 & 2 & 51 & 24 & 55 & 9 & 0 & 6 \\
\hline Buket & 2 & 4 & 10 & 18 & 8 & 6 & 14 & 25 & 19 & 64 & 29 & 40 & 32 & 4 & 5 \\
\hline Hallertauer tradition & 2 & 0 & 10 & 21 & 4 & 11 & 32 & 20 & 7 & 62 & 21 & 40 & 32 & 6 & 0 \\
\hline Nugget & 2 & 18 & 5 & 18 & 19 & 10 & 2 & 4 & 5 & 65 & 35 & 36 & 26 & 28 & 7 \\
\hline Smooth Cone & 2 & 0 & 10 & 16 & 9 & 11 & 11 & 12 & $\mathbf{5 0}$ & 62 & 29 & 40 & 37 & 11 & 3 \\
\hline Cekin & 2 & 14 & 18 & 16 & 3 & 10 & 5 & 3 & 0 & 47 & 15 & 60 & 22 & 3 & 4 \\
\hline Bobek & 2 & 0 & 5 & 13 & 7 & 5 & 4 & 7 & 14 & 67 & 18 & 55 & 33 & 6 & 4 \\
\hline Aurora & 2 & 0 & 0 & 12 & 11 & 11 & 5 & 4 & 5 & 55 & 22 & 64 & 34 & 8 & 6 \\
\hline Northeren Brewer & 2 & 0 & 3 & 20 & 7 & 6 & 2 & 5 & 2 & 56 & 27 & 64 & 8 & 4 & 3 \\
\hline Southeren Brewer & 3 & 5 & 62 & 18 & 19 & 31 & 33 & 65 & 54 & 58 & 39 & 33 & 14 & 25 & 22 \\
\hline Spalt Select & 3 & 0 & 85 & 17 & 13 & 21 & 14 & 65 & 45 & 55 & 5 & 55 & 3 & 0 & 0 \\
\hline First Choice & 3 & 0 & 38 & 45 & 62 & 13 & 4 & 12 & 17 & 100 & 9 & 64 & 17 & 5 & 4 \\
\hline Golden Star & 3 & 0 & 27 & 55 & 34 & 5 & 17 & 18 & 0 & 55 & 62 & 27 & 13 & 4 & 3 \\
\hline Kirin 2 & 3 & 0 & 25 & 51 & 34 & 2 & 10 & 23 & 2 & 65 & 66 & 20 & 8 & 3 & 3 \\
\hline Petrovački červenjak & 3 & 0 & 0 & 32 & 9 & 26 & 34 & 45 & 55 & 24 & 0 & 20 & 33 & 19 & 18 \\
\hline Bullion & 3 & 0 & 8 & 19 & 11 & 23 & 14 & 19 & 29 & 80 & 40 & 20 & 14 & 18 & 4 \\
\hline Willamatte & 3 & 0 & 5 & 18 & 6 & 6 & 7 & 3 & 10 & 68 & 43 & 45 & 7 & 3 & 2 \\
\hline Blisk & 3 & 0 & 0 & 0 & 5 & 5 & 8 & 9 & 24 & 65 & 30 & 20 & 10 & 5 & 3 \\
\hline Fukujutaka & 3 & 0 & 12 & 14 & 3 & 0 & 7 & 30 & 17 & 85 & 18 & 30 & 7 & 10 & 3 \\
\hline Kitamidori & 4 & 0 & 0 & 22 & 4 & 13 & 25 & 21 & 17 & 41 & 22 & 100 & 32 & 5 & 1 \\
\hline Dunav & 4 & 9 & 3 & 18 & 8 & 9 & 9 & 31 & 10 & 70 & 26 & 73 & 22 & 5 & 4 \\
\hline Neoplanta & 4 & 0 & 13 & 28 & 7 & 12 & 12 & 27 & 19 & 56 & 31 & 50 & 2 & 0 & 2 \\
\hline Vojvodina & 4 & 9 & 13 & 21 & 5 & 10 & 6 & 31 & 0 & 71 & 26 & 73 & 9 & 5 & 4 \\
\hline Cicero & 4 & 0 & 18 & 29 & 4 & 20 & 7 & 17 & 17 & 65 & 24 & 70 & 10 & 2 & 6 \\
\hline Magnum & 4 & 0 & 23 & 8 & 2 & 16 & 5 & 26 & 100 & 77 & 19 & 50 & 27 & 16 & 21 \\
\hline Calli Cross & 4 & 9 & 31 & 16 & 5 & 13 & 2 & 13 & 38 & 75 & 41 & 50 & 29 & 69 & 5 \\
\hline Keyworth Midseason & 4 & 13 & 10 & 25 & 17 & 24 & 29 & 35 & 31 & 70 & 76 & 73 & 3 & 4 & 2 \\
\hline Apolon & 4 & 0 & 0 & 0 & 5 & 4 & 11 & 8 & 36 & 71 & 13 & 20 & 24 & 18 & 9 \\
\hline Brewers Gold & 4 & 0 & 1 & 14 & 12 & 11 & 21 & 21 & 31 & 100 & 61 & 27 & 18 & 11 & 2 \\
\hline Atlas & 4 & 0 & 0 & 12 & 7 & 7 & 15 & 14 & 31 & 77 & 100 & 20 & 0 & 10 & 4 \\
\hline Ahil & 4 & 0 & 0 & 12 & 9 & 9 & 10 & 22 & 36 & 71 & 67 & 40 & 17 & 11 & 3 \\
\hline Symphony & 5 & 7 & 12 & 10 & 4 & 7 & 0 & 23 & 19 & 65 & 56 & 30 & 100 & 84 & 100 \\
\hline Yakima Cluster & 5 & 0 & 15 & 10 & 5 & 7 & 3 & 18 & 17 & 100 & 88 & 90 & 52 & 96 & 7 \\
\hline Galena & 5 & 0 & 15 & 14 & 12 & 18 & 2 & 28 & 98 & 68 & 100 & 80 & 68 & 100 & 40 \\
\hline
\end{tabular}

Susceptibility markers appeared in half of the cultivars in group 1 but they were more frequent in group 2 . Group 2 can be divided into 3 subgroups: subgroup 2a containing 27 cultivars with at least 1 resistance and no susceptibility marker; subgroup $2 \mathrm{~b}$ with 24 cultivars showing both types of markers, and subgroup 2c (8 cvs.) with only susceptibility markers. In groups 3, 4 and 5 , the number of susceptibility markers with high values increased. For example, marker 30 achieved extreme values in susceptible cultivars scored with 4 or
5. The same is true of markers 34 and 38, in which indexes increased in relation to susceptibility.

Analysis of the presence/absence of selected markers showed that the absence of susceptibility markers, particularly 30,34 and 38 , can be of practical value in resistance hop breeding. These markers were not found in cultivars scored 0 , and in less than half of the cultivars in groups 1 and 2 (33 cvs. out of 72). 


\section{DISCUSSION}

Resistance breeding is one of the most important aims in developing new hop cultivars. Marker assisted selection is an important tool in modern breeding, contributing to a shorter period required for breeding. Secondary metabolites are known to be disease defence compounds and biochemical markers for downy mildew and hop damson aphid have been developed in hop (Kralj et al., 1998). In the present work, we analysed the link between essential oil compounds and the resistance/susceptibility of hop cultivars to powdery mildew. Powdery mildew is a significant disease, the appearance of which depends on climatic conditions, and selection for resistance in the field can therefore be unreliable. Direct assessments of infection on cones are laborious, so the reported biochemical markers can significantly speed up and simplify the search for powdery mildew resistant genotypes.

We assessed disease on 103 cultivars from the world germplasm collection. Cultivars were divided into 6 disease groups, although it is very difficult to make a clear distinction among groups with semi-susceptible cultivars (groups 2 and 3), while resistant (groups 0 and 1) and highly susceptible (groups 4 and 5) cultivars were clearly distinguished. The assignment of the cultivars into disease groups depended on the resistance/susceptibility of cultivars to $S$. humuli pathotypes present in our conditions.

Based on field assessments of hop resistance to powdery mildew and chromatographic analysis of their essential oils in the hop cones, 7 susceptibility markers and 7 resistance markers were identified. These markers are differently distributed and have different values among the analysed cultivars. Accordingly, a cultivar was considered resistant only when susceptibility markers were absent and resistance markers with high indexes were present (Table 1). Similarly, a cultivar was classified as susceptible when susceptibility markers were present and resistance markers were absent or had very low indexes. These results can be of practical value in breeding, since it has been shown that the absence of susceptibility markers, particularly 30,34 and 38, can indicate the resistance of a hop genotype.

Our results also support the hypothesis that selinenes are involved in powdery mildew resistance (Liyanage, 1973; Darby, 1998b), since alpha-selinene is one of the resistance markers (marker 118) detected in our analysis. This marker was absent in susceptible cultivars in groups 4 and 5, although its presence in resistant cultivars was not consistent and it cannot therefore be used as a reliable marker.

Cultivars in groups 4 and 5 mainly contain North American germplasm according to studies of genetic diversity of hop genotypes (Sustar-Vozlič et al., 1999, Stajner et al., 2007). On the other hand, resistant cultivars belong to European hops, such as Czech Saazer, traditional German hops (Strisselspalt) and many cultivars of English origin. The same relation between susceptibility to downy mildew and the origin of germplasm was made in a previous paper on the determination of markers related to resistance to downy mildew (Kralj et al., 1998).

The above results showed a link between the content of essential oil compounds and resistance to powdery mildew, which was the basis for detection of chemical markers. These markers can be used in resistance breeding, by essential oil analysis of the breeding material and selection of resistant plants based on high indexes of resistance markers and low indexes of susceptibility markers.

\section{ACKNOWLEDGEMENT}

This study was funded by the Slovenian Ministry of Higher Education, Science and Technology. We would like to thank Prof. Dr. Samo Kralj for his assistance.

\section{REFERENCES}

Bobes, I., Florea, N., Otoin, M. (1981): Buletinul Agronomic. Cluj - Napora, Agricultura, 35: 103-107.

Darby, P. (1998 a): The symptoms and biology of Hop Powdery Mildew. In: Hop powdery Mildew Electronic Symposium, presentation from the 1998 US Hop Industry
Joint Meeting, Yakima, Washington, January 19-23, http://wwwscisoc.org/hpmes/darby.htm.

Darby, P. (1998 b): UK Research Offer Advice on Hop Powdery Mildew. Brewers Digest, 2: 24-26. 
Kralj, D., Kač, M., Dolinar, M., Žolnir, M., Kralj, S. (1998): Marker-assisted hop (Humulus lupulus L) breeding. Monatsschrift für Brauwissenschaft, 7/8: 111-119.

Krofta, K., Nesvadba, V. (2003): How hop powdery mildew influences the quality of hops and beer? In: Proceedings of the Scientific Commission, pp. 58-62. Ed. Seigner E. Dobrna - Žalec, Slovenia: International Hop Growers Convention.

Liyanage, A., De, S. (1973): Studies on resistance and overwintering in hop powdery mildew (Sphaerotheca Humuli). PhD Thesis, University of London, Wye College.

Ocamb, C.M., Klein, R., Barbour, J., Griesbach, J., Mahaffee, W.F. (1999): First Report of Hop Powdery Mildew in the Pacific Northwest. Disease Notes. Plant Disease, 83: 11.

Olson, R. (1998): Hop Damage Costly. Southern Draft Brewer News, December 1997/Januar 1998.

Royle, D.J. (1978): Powdery Mildew of the Hop. In: The Powdery Mildews (Ed. by D.M. Spencer), Academic Press, London: 381-409.

Seefelder, S., Lutz, A., Seigner, E. (2006): Development of molecular markers for powdery mildew resistance support breeding for high quality hops. Monatsschrift für Brauwissenschaft, 5/6: 100-102.

Seigner, E., Lutz, A., Radic-Miehle, H., Seefelder, S. (2005): Breeding and development of hop varieties at the Hop research center Hüll. In: Proceedings of the Scientific Commission, pp. 18-22. Ed. Seigner E. George, South Africa: International Hop Growers Convention.

Spearman, C. (1905): General intelligence objectively determined and measured. American Journal of Psychology, 15: 201-93.

Stajner, N., Satovic, Z., Cerenak, A., Javornik, B. (2007): Genetic structure and differentiation in hop (Humulus lupulus L.) as inferred from microsatellites. Euphytica DOI 10.1007/s10681-007-9429-z.

Sustar-Vozlic, J., Javornik, B. (1999): Genetic relationships in cultivars of hops, Humulus lupulus L., as determined by RAPD analysis. Plant Breeding, 118: 175-181.

Turechek, W.W., Mahafee, W.F., Ocamb, C.M. (2001): Development of Managment Strategies for Hop Powdery Mildew in the Pacific Northwest. Plant Health Progress doi: 10.1094/PHP-2001-0313-01-RS. 